\title{
EFFECT OF PROBIOTIC AND PREBIOTIC CONSUMPTION ON BLOOD CHOLESTEROL LEVEL IN THE ELDERLY IN POSYANDU MANISJANGAN YOGYAKARTA
}

\author{
Diyan Yunanto Setyaji ${ }^{*}$, Fransisca Anjar Rina Setyani ${ }^{2}$ \\ ${ }^{\mathbf{1}}$ Bachelor Nutrition Programme, Sekolah Tinggi Ilmu Kesehatan Panti Rapih \\ Tantular st 401, Pringwulung, Condongcatur, Depok, Sleman 55283, Indonesia \\ ${ }^{2}$ Nurse Profession Education, Sekolah Tinggi Ilmu Kesehatan Panti Rapih \\ Tantular st 401, Pringwulung, Condongcatur, Depok, Sleman 55283, Indonesia \\ *Korespondensi: diyansetyaji@stikespantirapih.ac.id
}

\begin{abstract}
Background: With advanced age, an increase in lipid profile is associated with the incidence of cardiovascular disease. Previous studies showed that the administration of probiotic and/or prebiotic are effective in improving lipid profiles. However, other studies have also shown that probiotic and prebiotic had insignificant effects on lipid profiles.

Objectives: Determined the effects of probiotic and prebiotic on blood cholesterol level in the elderly.

Methods: A total of 64 elderly who did not take cholesterol-lowering drugs enrolled in the quasi-experiment pretestposttest design and were assigned to three interventions and control groups. The subjects in PRE-group consumed 100 grams of mung bean porridge per day; the subjects in PRO-group consumed $65 \mathrm{ml}$ of fermented milk enriched with Lactobacillus casei Shirota strain per day; the subjects in PREPRO-group consumed 100 grams of mung bean porridge and $65 \mathrm{ml}$ of fermented milk enriched with Lactobacillus casei Shirota strain per day. All intervention groups received treatment for 4 weeks. The control group did not receive any treatment during the study. Before and after treatment, cholesterol data was collected. Paired t-test, ANOVA, Post-hoc LSD were used for statistical analysis.

Results There was an increase in cholesterol levels in PRE, PRO, PREPRO-groups (12.93 mg/dL; $48.37 \mathrm{mg} / \mathrm{dL}$; and 7.62 $\mathrm{mg} / \mathrm{dL}$ ). Among the three intervention groups, only the consumption of probiotic was significant for changes in blood cholesterol levels ( $\mathrm{p}$ 0.023). The administration of various interventions did not have a significant effect on changes in cholesterol levels (p 0.246) when compared to the control group.

Conclusion: Prebiotic and probiotic do not lower blood cholesterol level in the elderly in Posyandu Manisjangan Yogyakarta.

Keywords : Probiotic; Prebiotic; Cholesterol; Elderly
\end{abstract}

\begin{abstract}
ABSTRAK
Latar belakang: Seiring dengan bertambahnya usia, meningkatnya profil lipid berhubungan dengan kejadian penyakit kardiovaskular. Penelitian sebelumnya menunjukkan bahwa pemberian probiotik dan atau prebiotik efektif dalam memperbaiki profil lipid. Namun, penelitian lain menunjukkan bahwa efek dari pemberian probiotik dan prebiotik tidak signifikan terhadap profil lipid.

Tujuan: Mengetahui pengaruh dari pemberian probiotik dan prebiotik terhadap kadar kolesterol darah pada lansia. Metode: Sejumlah 64 lansia yang tidak mengonsumsi obat penurun kolesterol mengikuti penelitian kuasi eksperimental dengan desain prepost dan digolongkan ke dalam 3 kelompok intervensi dan 1 kelompok kontrol. Responden pada kelompok PRE mengonsumsi 100 gram bubur kacang hijau setiap hari; responden pada kelompok PRO mengonsumsi 65 ml susu fermentasi yang diperkaya dengan Lactobacillus casei Shirota strain setiap hari; responden pada kelompok PREPRO mengonsumsi 100 gram bubur kacang hijau dan $65 \mathrm{ml}$ susu fermentasi yang diperkaya dengan Lactobacillus casei Shirota strain setiap hari. Semua kelompok intervensi menerima perlakuan selama 4 minggu. Kelompok kontrol tidak mendapatkan perlakuan apapun selama waktu penelitian. Sebelum dan sesudah perlakuan dilakukan pengambilan data kolesterol. Uji paired t-test, ANOVA, Post-hoc LSD digunakan dalam analisa statistik.

Hasil: Terdapat peningkatan kadar kolesterol pada kelompok PRE, PRO, dan PREPRO (12,93 mg/dL; 48,37 mg/dL; dan 7,62 mg/dL). Di antara ketiga kelompok intervensi, hanya konsumsi probiotik yang signifikan secara statistik dalam perubahan kadar kolesterol darah (p 0,023). Pemberian berbagai perlakuan tidak memiliki efek yang signifikan di dalam perubahan kadar kolesterol (p 0,246) ketika dibandingkan dengan kelompok kontrol.

Simpulan: Pemberian prebiotik dan probiotik tidak menurunkan kadar kolesterol darah pada lansia di Posyandu Manisjangan Yogyakarta.
\end{abstract}

Kata Kunci : Probiotik; Prebiotik; Kolesterol; Lansia 


\section{INTRODUCTION}

The loss of the body's ability to maintain cholesterol homeostasis results in cholesterol metabolism abnormalities such as hypercholesterolemia, which is closely related to the development of cardiovascular diseases including atherosclerosis, coronary heart disease, and stroke. Cardiovascular diseases are the leading causes of death in the world with 17.9 million deaths (32.1\%) in 2015, an increase from 12.3 million deaths $(25.8 \%)$ in $1990 .{ }^{1}$ The 2018 Indonesian Basic Health Research shows that the prevalence of heart disease based on doctor's diagnosis in all age groups is $1.5 \%$, while the prevalence of stroke based on doctor's diagnosis in the age group over 15 years has increased from 7 per-mille in 2013 to 10.9 per-mille in 2018. ${ }^{2}$

Probiotics are live microorganisms that benefit human health when consumed in adequate amounts. Specific strains of probiotic bacteria, such as Lactobacillus, have been shown to increase antidiarrhea and anti-inflammatory properties, boost immunity, and delay diabetes. ${ }^{3}$ Several Lactobacillus strains have been found to reduce total cholesterol and triglyceride levels in mice, while in human clinical studies there is no consensus on the effect of ingestion of Lactobacillus strains on lipid profiles. Fuentes et al. reported that daily intake of $L$. plantarumin capsules containing $1.2 \times 10^{9} \mathrm{CFU}$ decreased the concentration of total cholesterol and LDL cholesterol in participants with hypercholesterolemia after 12 weeks. ${ }^{4}$ However, Hove et al reported that 12 weeks of intake of milk fermented with L. helveticus had no effect on serum lipids in type 2 diabetes patients. ${ }^{5}$

Dietary fibers are the edible portion of plants that is resistant to enzymatic digestion and absorption by the intestinal tract. Dietary fibers have attracted considerable attentions owing to their significant roles being prebiotic. Prebiotic is defined as selectively fermented complex ingredients/carbohydrates that cause and promote specific changes, in the structure and/or function of the GIT bacterial flora, thereby exerting potential health benefits upon host health. ${ }^{6}$ Prebiotic strengthen the benefits of probiotic through their colonization enhancement mechanism. Consumption of probiotic and prebiotic provides additional but not synergistic effects. ${ }^{7}$ Recent in vitro studies have shown that interventions with a combination of probiotics and prebiotics significantly reduce levels of total cholesterol, LDL cholesterol, and triglycerides in rats with hypercholesterolemia. ${ }^{8}$ Prebiotic exist in asparagus, sugar beet, garlic, chicory, onion, Jerusalem artichoke, wheat, honey, banana, barley, tomato, rye, soybean, human's and cow's milk, peas, beans, seaweeds, and microalgae. ${ }^{9}$ The total content of dietary fiber in 100 grams of mung bean porridge is 19.38 grams. $^{10}$

The results of checking blood cholesterol levels through a preliminary survey conducted on the elderly at the Posyandu Manisjangan stated that $80 \%$ of the elderly had total cholesterol levels above the normal level $(\geq 180 \mathrm{mg} / \mathrm{dL})$. The elderly expressed their fondness for consuming greasy foods such as fried foods as snacks because they are cheap and easily accessible. This behavior is not followed by the elderly's habit of consuming vegetables and fruit.

Consumption of products containing probiotics and prebiotics is one of the nonpharmacological measures that can be used to reduce cholesterol levels in the blood. Although this food product is easily obtained by the elderly at a relatively affordable price, this has not been done by the elderly at the Posyandu Manisjangan, Yogyakarta. Seeing these problems, researchers are interested in conducting research by providing nonpharmacological interventions by consuming food products containing probiotics and prebiotics in the elderly at the Posyandu Manisjangan, Yogyakarta. This study was conducted with the aim of analyzing the effect of probiotic and prebiotic products on the blood cholesterol levels of the elderly at Posyandu Manisjangan Yogyakarta.

\section{METHODS}

Ethical clearance with approval number 080.3/FIKES/PL/III/2020 was obtained from the Komisi Etik Penelitian Kesehatan, Fakultas Ilmu Kesehatan, Universitas Respati Yogyakarta. All volunteers gave their written informed consent. Eligible for the study were healthy men and women 55-87 years old who did not use any medications known to affect blood lipid metabolism. Sixty-nine volunteers were screened and 66 were enrolled. Two subjects were dropped out due to changing her residence and experiencing uric acid disorders. A total of 64 elderly who did not take cholesterollowering drugs enrolled in the quasi experiment pre post test design and were assigned to three interventions groups and control. The study was completed by 16 subjects in each of groups.

The subjects in PRE-group received prebiotic by consumed 100 grams of mung bean porridge containing 19.38 gram total dietary fiber daily for 4 week; the subjects in PRO-group received probiotic by consumed $65 \mathrm{ml}$ of fermented milk containing $6.5 \times 10^{9}$ live cells of Lactobacillus casei strain Shirota daily for 4 week; the subjects in PREPRO-group received prebiotic and probiotic by consumed 100 grams of mung bean porridge and 65 $\mathrm{ml}$ of fermented milk containing $6.5 \times 10^{9}$ live cells of Lactobacillus casei strain Shirota daily for 4 
week. The control group did not receive any treatment during the study. Mung bean porridge rich in dietary fiber as a source of prebiotic prepared by posyandu cadres without adding cane sugar and coconut milk. Researchers distributed mung bean porridge and fermented milk every morning after the subjects had breakfast. Researchers did not change the diet and eating habits of all subjects. To assess cholesterol concentrations, fingerstick capillary specimens were taken after ten hours fasting. A 1.1 $\mu 1$ blood samples of all subjects were taken by registered nurses using Easy Touch GCU-meter device.

\section{RESULTS}

The subjects cholesterol levels were obtained in two measurements. The average cholesterol level of all subjects before the intervention was $179.18 \mathrm{mg} / \mathrm{dL}$. Subjects were divided into four groups: control and three intervention groups who received prebiotic, probiotic, and both prebiotic and probiotic for 4 weeks. The average cholesterol level of all subjects in the second measurement after the intervention was $204.59 \mathrm{mg} / \mathrm{dL}$. The average change in cholesterol levels in all subjects was $25.40 \mathrm{mg} / \mathrm{dL}$.

In the pre-treatment and post-treatment data, the Paired $\mathrm{T}$ test was performed to determine the significant differences in cholesterol levels. In all intervention groups, there was an increase in cholesterol levels after giving prebiotics and/or probiotics for 4 weeks $(12.93 \mathrm{mg} / \mathrm{dL}$ in the PRE group; $48.37 \mathrm{mg} / \mathrm{dL}$ in the PRO group; and 7.62 $\mathrm{mg} / \mathrm{dL}$ in the PREPRO group). Of the 3 intervention groups, only the group that consumed probiotics reported significant changes in blood cholesterol levels (p 0.023).

Table 1. Cholesterol Level after 4 Weeks Intervention

\begin{tabular}{|c|c|c|c|c|c|c|}
\hline \multirow{2}{*}{ Groups } & \multirow{2}{*}{$\mathbf{n}$} & \multicolumn{3}{|c|}{ Cholesterol Level (mg/dl) } & \multirow{2}{*}{$\underset{\text { (paired t-test) }}{p}$} & \multirow{2}{*}{$\begin{array}{c}p \\
\text { (ANOVA) }\end{array}$} \\
\hline & & Pre-treatment & Post-treatment & $\Delta$ & & \\
\hline Control & 16 & $173,43 \pm 53,23$ & $206,12 \pm 31,33$ & 32,68 & $0,037 *$ & \multirow{4}{*}{0.246} \\
\hline PRE & 16 & $180,81 \pm 46,40$ & $193,75 \pm 37,82$ & 12,93 & 0,342 & \\
\hline PRO & 16 & $179,12 \pm 46,32$ & $227,50 \pm 52,49$ & 48,37 & $0,023 *$ & \\
\hline PREPRO & 16 & $183,37 \pm 56,21$ & $191,00 \pm 53,45$ & 7,62 & 0,635 & \\
\hline
\end{tabular}

*significantly different $(p<0.05)$

Analysis of One-way ANOVA at posttreatment for increased cholesterol levels obtained $\mathrm{p}$ 0.246 , it can be concluded that the administration of various interventions did not have a significant effect on changes in cholesterol levels when compared to the control group. A follow-up analysis with Post- hoc LSD was performed to see the comparison between the control group and the various intervention groups showing that there was a relationship that was not statistically significant. The results of the analysis between the intervention groups also showed an insignificant relationship.

Table 2. Post-hoc LSD

\begin{tabular}{lc}
\hline Comparison & $\begin{array}{c}p \\
\text { (post-hoc LSD) }\end{array}$ \\
\hline Control - PRE & 0,378 \\
Control - PRO & 0,483 \\
Control - PREPRO & 0,264 \\
PRE - PRO & 0,116 \\
PRE - PREPRO & 0,812 \\
PRO - PREPRO & 0,072 \\
\hline *significantly different $(p<0.05)$ &
\end{tabular}

\section{DISCUSSIONS}

The group of subjects who consumed fermented milk containing $6.5 \times 10^{9}$ live cells of Lactobacillus casei strain Shirota daily reported an increase in blood cholesterol levels after 4 weeks of intervention. This may be due to the impact of the sugar content in fermented milk and the ability to colonize the bacteria contained in it. The sugar content in fermented milk consumed is 10 grams per $65 \mathrm{ml}$. Consuming moderate amounts in sugar has been shown to increase total serum cholesterol and triglycerides. A diet high in sucrose is associated with an elevation of plasma triglyceride concentrations. This increase is due to both increased hepatic secretion and impaired clearance of verylow-density lipoprotein. ${ }^{11}$ Hyperglycemia lead to 
glycated low-density lipoproteins cholesterol and hyperinsulinemia increasing lipogenesis. ${ }^{12}$

Products that contain live bacteria, such as yogurt, acidophilus milk, and kefir contain strains that are not normally present in the human intestinal tract. As a result, these bacteria are unable to colonize the intestines and are quickly excreted in feces. Thus, daily consumption of probiotic products is necessary for long-term effects on metabolism. Administration of Lactobacillus acidophilus L1 did not affect blood lipid profiles in adults with cholesterol levels of 3.9-7.8 mmol/1 after a 6-week treatment period. ${ }^{13}$

In another study involving healthy volunteers, consumption of Lactobacillus plantarum $299 v$ did not contribute to changes in serum cholesterol after 6 weeks. ${ }^{14}$ In a study evaluating the effect of Bifidobacterium longum BLl on serum cholesterol, 32 subjects with serum total cholesterol ranging from 220 to $280 \mathrm{mg} / \mathrm{dL}$ were randomized to two treatments, taking probiotics $3 \times 100 \mathrm{~mL} /$ day or plain yogurt (fermented by Streptococcus thermophilus and Lactobacillus subsp. Bulgaricus) for 4 weeks. In this study, there weren't any significant changes in blood cholesterol level during the trial period. ${ }^{15}$ Similarly, although some lipid parameters changed after 4 weeks of oral probiotics or conventional yogurt, no significant difference between groups was observed. ${ }^{16}$ In a study by Simons et al, 44 volunteers (baseline total cholesterol $\geq 4.0 \mathrm{mmol} / \mathrm{l}$ ) took two capsules twice daily for a period of 10 weeks. The researchers demonstrated that the Lactobacillus fermentum capsules did not significantly change the serum cholesterol of the subjects. ${ }^{17}$

The group of subjects who consumed mung bean porridge every day reported an increase in blood cholesterol levels after 4 weeks of intervention. This may be due to the impact of prebiotic fermented products and the inadequate amount of dietary fiber to support the life of probiotic colonies. Prebiotics may have a detrimental effect on lipid profile through producing acetate. Acetate can be converted to acetyl-CoA, which is a substrate to synthesize fatty acids in hepatocytes. ${ }^{18}$ Moderate intake of inulin or oligofructose may affect human lipid metabolism. Although convincing lipid-lowering effects of inulin and oligofructose have been observed in animals, studies were carried out at relatively high doses (50 to $200 \mathrm{~g} / \mathrm{kg}$ body weight). The equivalent dose cannot be used in humans because of known adverse gastrointestinal side effects at intake levels above 30 g/day. ${ }^{19}$

In studies conducted on normallipidemic subjects, no effect of inulin or oligofructose was reported on serum lipids, whereas other studies reported significant reductions in serum triglycerides with smaller changes in serum total and LDL cholesterol. Available data suggest that in subjects with hyperlipidemia any effect that occurs primarily results in a reduction in cholesterol. In subjects with normal cholesterol levels, the dominant effect appeared on changes in serum triglyceride levels. ${ }^{19}$ This led us to conclude that the hypocholesterolemic action of prebiotic is modified by dietary cholesterol, and therefore the hypocholesterolemic response in human subjects may vary depending on whether the individual is normal or hypercholesterolemic.

The determinant factor that affects changes in blood cholesterol levels is age. The concentration of plasma cholesterol increases with age from puberty until 45 to 55 years of age in men, then decreases. In women, it continues to increase until about 10 years later, after which it declines in the last decades of life. The factors that determine plasma cholesterol concentration are varied and depend on the specific circumstances of the elderly patient. They include diet, exercise, and metabolic disorders. ${ }^{20}$

Diets rich in cholesterol and saturated and trans fats increase the concentration of LDL cholesterol. Certain intraluminal conditions in the intestine, such as increased transit time or the cholesterol content of bile, can also increase LDL concentration. Both factors are present in the elderly. ${ }^{21}$ A high proportion of the elderly have a sedentary lifestyle. High plasma cholesterol is a result of the interaction between unhealthy lifestyle habits or concomitant diseases and other genetic disorders. ${ }^{22}$

This study has many limitations. First, the method of checking cholesterol levels that we cannot see the composition of the lipid profile. Second, We did not measure the daily dietary intake of the elderly during the intervention period. Finally, Consumption of prebiotic is only 100 grams per day and probiotics $65 \mathrm{ml}$ per day with a duration of intervention of 4 weeks. We suggest further consideration and research concentrating on determining the mechanisms underlying the cholesterol-lowering effect of probiotics, the ability of probiotics to survive in the large intestine, the role of prebiotic in maintaining adequate probiotic survival and colonization of cholesterol-lowering probiotic species and identifying the effects of prebiotic consumption on postprandial triglycerides.

\section{CONCLUSIONS}

It is suggested that mung bean as a source of prebiotic and fermented milk enriched with Lactobacillus casei Shirota strain as a probiotic do not lower blood cholesterol level in the elderly in 
Posyandu Manisjangan Yogyakarta. Several factors should be taken into account in further studies including the ratio of carbohydrate to fat intake in the diet of the elderly, treatment duration, and serum lipid profiles as variables that might influence the outcome.

\section{ACKNOWLEDGMENT}

We thank to the Kementerian Riset dan Tecnology, Republik Indonesia for funding this study. We are greatly indebted to our volunteers for taking part in this study and to cadre of Posyandu Manisjangan Yogyakarta for preparing and delivering prebiotic and probiotic product to our volunteers. We would like to thank Bambang Budi Istiarjo for giving permission and accompanying research activities in the Mangkukusuman Village.

\section{REFERENCES}

1. WHO. World health statistics 2018: Monitoring health for the SDGs, sustainable development goals. Geneva; World Health Organization 2018.

2. National Institute of Health Research Development (NIHRD). Laporan Nasional Riskesdas 2018. Jakarta; Lembaga Penerbit Badan Penelitian dan Pengembangan Kesehatan 2019.

3. Aguirre M, Bussolo de Souza C, Venema K. The gut microbiota from lean and obese subjects contribute differently to the fermentation of arabinogalactan and inulin. PLOS ONE 2016; 11(7): 1-18.

4. Fuentes MC, Lajo T, Carrion JM, et al Cholesterol-lowering efficacy of lactobacillus plantarum CECT 7527, 7528 and 7529 in hypercholesterolaemic adults. British Journal of Nutrition 2013; 109: 1866-1872.

5. Hove KD, Faerch K, Lund SS, et al. Effects of 12 weeks of treatment with fermented milk on blood pressure, glucose metabolism and markers of CVD risk in patients with type 2 diabetes: a randomised double-blind placebocontrolled study. European Journal of Endocrinology 2015; 172: 11-20.

6. Gibson GR, Scott KP, Rastall RA, et al. Dietary prebiotics: Current status and new definition. Food

Science \& Technology Bulletin: Functional Foods 2010: 7(1), 1-19.

7. Femia AP, Luceri C, Dolara $\mathrm{P}$, et al. Antitumorigenic activity of the prebiotic inulin enriched with oligofructose in combination with the probiotics Lactobacillus rhamnosus and Bififidobacterium lactis on azoxymethane- induced colon carcinogenesis in rats. Carcinogenesis 2002; 23(11): 1953-60.

8. Aktimur SH, Suher M, Darilmaz DO, et al. Effects of probiotics, prebiotics and symbiotics on serum cholesterol levels. Clinic in Surgery 2017; 2(1652):1-3.

9. Panesar PS, Kumari S, Panesar R. Biotechnological approaches for the production of prebiotics and their potential applications. Crit. Rev. Biotechnol 2013; 33: 345-364.

10. Tan CX, Azrina A. Dietary fiber and total phenolic content of selected raw and cooked beans and its combinations. International Food Research Journal 2017; 24(5): 1863-1868.

11. Howard BV, Wylie-Rosett J. Sugar and Cardiovascular Disease. Circulation. 2002; 106: 523-527.

12. DiNicolantonio JJ, Lucan SC, O'Keefe JH. The evidence for saturated fat and for sugar related to coronary heart disease. Prog Cardiovasc Dis 2016; 58(5): 464-472.

13. de Roos NM, Schouten G, Katan MB. Yogurt enriched with Lactobacillus acidophilus does not lower blood lipids in healthy men and women with normal to borderline high serum cholesterol levels. European Journal of Clinical Nutrition 1999; 53: 277-280.

14. Naruszewicz M, Johansson ML, ZapolskaDownar D, et al. Effect of Lactobacillus plantarum 299v on cardiovascular disease risk factors in smokers. American Journal of Clinical Nutrition 2002;76: 1249-1255.

15. Xiao JZ, Kondo S, Takahashi S. Effects of milk products fermented by Bifidobacterium longum on blood lipids in rats and healthy adult male volunteers. Journal of Dairy Science 2003; 86:2452-2461.

16. Fabian E, Elmadfa I. Influence of daily consumption of probiotic and conventional yoghurt on the plasma lipid profile in young healthy women. Annals of Nutrition and Metabolism 2006; 50:387-393.

17. Simons LA, Armansec SG, Conway P, et al. Effect of Lactobacillus fermentum on serum lipids in subjects with elevated serum. Nutrition Metabolism and Cardiovascular Disease 2006; 16: 531-535.

18. Davani-Davari D, Negahdaripour M, Karimzadeh I, Seifan M, Mohkam M, Masoumi SJ, et al. Prebiotics: Defifinition, types, sources, mechanisms, and clinical applications. Foods 2019; 8: 92.

19. Delzenne NM, Kok N, Fiordaliso MF, et al. Dietary fructooligosaccharides modify lipid metabolism in rats. American Journal of Clinical Nutrition 1993; 57(5): 820S. 
20. Félix-Redondo FJ, Grau M, Fernández-Bergés D. Cholesterol and cardiovascular disease in the elderly: Facts and gaps. Aging and Disease 2013; 4(3); 154-169.

21. Reiner Z, Catapano AL, De Backer G, Graham I, Taskinen MR, Wiklund et al. The task force for the management of dyslipidaemia of the European Society of Cardiology and the European Atherosclerosis Society. ESC/EAS Guidelines for the management of dyslipidaemia. Eur Heart J 2011; 32:1769-818.

22. Healy GN, Clark BK, Winkler EA, Gardiner PA, Brown WJ, Matthews CE. Measurement of adults' sedentary time in population-based studies. Am J Prev Med 2011, 41:216-27. 